\title{
The Art Creation in The Traditional Art Area
}

\author{
Esthi Nimita, Mustika Yundari \\ Universitas Persada Indonesia YAI \\ Jalan Diponegoro No. 74 Jakarta 10340, Indonesia
}

\begin{abstract}
ABSTRAK
Artikel ini membahas konsep penciptaan suatu karya seni dalam lingkup seni tradisional. Persoalan yang diangkat mengenai perlunya kita memahami bagaimana sebuah karya seni itu diciptakan dalam konteks tradisi, dan apa bedanya dengan penciptaan karya seni pada konteks modern, dengan pembahasan apa itu seni tradisional dan apa itu seni modern. Dengan mengambil contoh seni tari tradisi Jawa, tulisan ini menggunakan teori flow dari Csikszentmihalyi (1990) dan konsep taksu, penelitian ini mengungkapkan bahwa dalam melalui proses kreatifnya seorang seniman dapat memahami secara lebih dalam bagaimana sebuah karya seni itu diciptakan, sehingga seseorang dapat memiliki perspektif yang lebih baik mengenai hidup, kehidupan, dan hubungannya dengan Sang Pencipta sebagaimana terkandung dalam seni tersebut.
\end{abstract}

Kata kunci: seni tradisional, seni modern, proses penciptaan, tari tradisional, teori flow, taksu

\begin{abstract}
This article discusses the concept of creating an art work within a traditional art scope. The problem discussed is about understanding of art works that is created in the context of tradition, and what is the difference with the creation of art in the modern context. By using the example of Javanese tradisional dance, this article applies the flow theory from Csikszentmihalyi (1990) and the concept of taksu. The result is that in its creative process an artist could understand more deeply how art work is created so that the person could have a better perspective about life, and the conjunction with God as embodied in the art.
\end{abstract}

Keywords: traditional art, modern art, creating process, traditional dance, flow theory, taksu 


\section{INTRODUCTION}

Have you enjoyed the artwork until you feel heart beat? For example, in the field of dance is a classical Javanese dance. If the traditional Javanese dance is enjoyed, the allure of this dance can penetrate to the heart. This dance not only attracts the audience, but also provides a variety of inner experiences for the dancer. For example, the author's experience in dancing traditional Javanese dance is an experience that penetrates deeply into the author's self. For the writer, the slow and meditative tempo of the dance, as if stopping the chasing time out there, forces the focus on oneself to be more honest about living. Moreover, when the author studies the symbols created in the meaning of motion, the meaning of the story behind the dance, the tools of the clothes worn, the pattern of the floor and so on, the author drifts in His creation and His work.

Symbolizing the traditional art, according to some experts, has various interpretations, like in a dance. Full of meanings that aims to deliver messages about life and living and its relationship with the Creator for both the dancers and its audiences. The traditional classical dance created by the old dance mastersis so great and soulless. This raises curiosity, how the masters created this kind of art works? From where the idea came from?

This paper is made based on the author's curiosity, whether there is the difference between creating a traditional art work and a modern one. This paper discusses deeply some problems using related theoretical frameworks; such as, how are the process of creating art works in traditional societyand in modern society? By understanding the differences between them, this will lead to the subject of contemplation for dance artists. Besides, it also will be understood why we need to preserve the richness of traditional arts of the country.

\section{METHOD}

This paper was compiled and developed based on the results of the interviews, literature review, behavioral observations and personal experiences of the author. The methods used for this process is a qualitative method with descriptive approach. The qualitative method is a strategy to utilize and collect information by studying the examined phenomenon, in which there are no restrictions against certain categories of analysis so that the depth, openness, and completeness of data can be obtained (Poerwandari, 2005: 43).

The descriptive approach is an effort of re-imagining the acquired understanding in order to obtain materials for writing or rewriting, which also contains the activities of rethinking, reflecting, recognizing, and revising (Aminuddin, 1998: 129 in Maryaeni, 2005: 77).

\section{RESULTS AND DISCUSSION}

\section{The Concept of The Creation of Art Works}

Listening to the history of art works creation in which the masters tooktimes to do a special ritual for the sake of an audience with the Almighty before creating arts, it seems almost impossible for the modern society because of its rationality to do creative processes in this way.

Modern society, today, is anthropocentric. Anthropocentris believes that everything is centered on the humanself or emphasizes on human supremacy (Baqir, 2013). So does creativity, it comes from the human itself, without trying to relate it to the God or any other higher power. We usually associate highly creative people with the word 'genius'. The meaning of the 'genius' itself according to the Oxford Dictionary is 'exceptional intellectual or creative power or other natural ability.' So the person who manage to produce great works, usually we call it 'genius'.

Whereas the word genius itself as ex- 
pressed in the Lexical Investigation, of dictionary.com, presentedin the civilization of ancient Rome, about $14^{\text {th }}$ century. It derives from the word 'genii ' or 'jinny ' or 'Genie'. 'Genii', 'Jinny' or 'Genie' which means spirit or beings from other dimensions which is saidthat he always keep an eye on every single human being and 'whispers' or gives ' insight ' in creating a work. While the ancient Greece believed that 'genii' on a word 'genius' is more like a guardian angel in which his presence helped the creative process

Is there really a creative genie that whispers the process of creating a work? Moreover, if we see that there are among the artists who look 'trance' in doing a work, sometimes we say it as possessed by something or kepanjingan. Of course it is difficult to be accepted by most people, especially in modern society. The academics who generally need 'objective' data to be analysed based on empirical observations, would reject this possibility. In academic circle, if there is no objective explanation of a state, then it would be signed as a mystical or occult.

A professor of psychology from Hungary, Mihaly Csikszentmihalyi was interested in researching this issue indeepth. Csikszentmihalyi raised the flow theory resulting of his research on maestros of art and literature in producing their works. The flow theory has long been known through various teachings, as learned by yogis in India, Taoist teachings in China or Zen Buddhism through consciousness achieved with strong discipline (Csikszentmihalyi, 1990: 20).

As written by Csikszentmihalyi, flow is a mental state in which a person is immersed in the activities he performs, with an energy that is focused on doing the full involvement, and really enjoy the process of such activities. Activities happen spontaneously, as if it happens automatically. He would not feel separated from activities he does. Basically, flow is marked when a person absorbs what he does with the utmost; the energy just flows. At that point, someone will feel very relaxed, comfortable and full of energy (Csikszentmihalyi, 1990: 53). It is the same with the trance condition, which is known by modern society that during trance, the artist is able to performed at the utmost, or produces a monumental work.

This situation is more or less the same as in Indonesia known as taksu. According to Bulantrisna Djelantik in a short introduction to the event of the Maestro \#6, 'taksu' is a totality of doing a work, where the ego of the actors has been merged and united with the flow of the universe as his intention to dedicate himself and his dance is only for the Almighty in total.

Although there seems to be silting in the explanation of taksu through the flow theory, this becomes a more empirical explanation with suggestions for achieving it (certainly not that easy). But, at least Csikszentmihalyi acknowledges that the flow conditions require consciousness of what is being done, and consciousness to the self just disappears. Similar to the above explanation, the self-consciousness of the perpetrator has dissolved, integrated with the greater consciousness of the universe, or the greater power that himself. (Csikszentmihalyi,1990: 63). The flow state makes the artist able to achieve the optimal experience and create great works (Csikszentmihalyi, 1990: 3).

As a vague illustration that occurs in concept of creativity or creation of work in a tradition society might be found in the songs used in wayangkulit as told by Widaryanto, a dance observer, during the discussion of traditional dance with Sanggar Ardhanari (2014). The song in the form of pangkur tells the story of the King wishing to pray in Sanggar Palanggatan, a place to pray for inspiration: 
"Tansamarpamoringsuksma/Sinuksmanyawinahyaingangasepi/Sinimpentelengingkalbu/pambukaningwarana/tarlensakingdi antarasadardantidaksadarliyeplayapingngaliyup/ pindhapesatingsupenal sumusuping rasa jati."

[No longer hidden from the glory of soul, which is read in silence, deposited in the depths of heart into the expression of selfconsciousness, between conscious and unconscious, like a flash of a dream infiltrating the true sense].

This process of creation is obviously not commonin modern society, but only in traditional societies, as expressed by a professor of Islamic study from George Washington University, Seyeed Houssein Nasr in his book Search of the Sacred (2010: 271). "In traditional civilization, the original artist was a person who was able to go back to the Origin, to go back to God, to the spiritual world, and not just to produce something different out of his own ego for the sake of being different."

In traditional societies, a true artist is one who is able to return to his authenticity, return to his God, to his spiritual world, and not only produces something different only for the purpose of his ego for wanting to be considered 'different'. This is the highest form of creativity.

As revealed by Widaryanto (interview, 2016), that the term created in Javanese is commonly referred to nitahake. The same word is used by the Catholic Credo in Javanese, which refers to Allah as ingkangnitahakebumilangit which means "Who created earth and heavens". Nitahake also means 'to order'. Therefore, in a traditional society, as in Java, an artwork is often anonymous, without an author's name; or if there is an author's name, this work is dedicated to a king who is believed to be the 'representative' of God in the world. As an example is the work of KRT SasmintaMardawa, or nicknamed Rama Sas, a highly respected dance teacher from nDalem Pudjokusuman,
Yogyakarta. Rama Sas offered his dance work to the sultan, who later became Yasan Dalem Hamengkubuwono IX, and then is known to the public as sultan's work.

\section{Modern Art and Traditional Art}

In fact, what makes divisions in arts between traditional and modern one. Historically, as it is written in the New World Encyclopedia, in the Industrial Revolution, this distinction began in the Renaissance era, about in the 16th century, started in Italy, and spreading throughout Europe. This period was marked by a movement in the fields of literature, philosophy, art, music, politics, science, etc., where the Renaissance is seen as an intellectual effort to learn and enhance secular and worldly forms as a new approach.

After the Renaissance, the industrial revolution began, around the period of 1750-1850, where massive changes started from Great Britain and spreaded throughout Western Europe, North America, Japan, and finally to the rest of the world. The term "industrial revolution" itself was introduced by Friedrich Engels and LouisAuguste Blanquidi mid-19th century.

The gradual process of economic and social changes and a long-term revolution became an irony, because they created a modern capitalist economic system. People increasingly used their minds to find a way to earn as much income as possible, so it began to appear materialism that continues to grow until now. Inner feeling exercise by relying on the eye of the heart that previously was the foundation in doing everything turned into a competition of intelligence. People became increasingly concerned with themselves, or their group.

Modernism does not only mean changes and newness; this is a particular point of view to the world. The particular philosophy is based on the rejection towards the theocentric perspective of reality: eliminat- 
ing God from the center of reality and putting human supremacy instead. Of course all these changes have profound effects on arts. As in modern European civilization, we could feel that the appearing art works expressed are more individual rather than universal. In other words, the arts that emerged after the Renaissance and the industrial revolution is more anthropocentric. The term used is a humanistic art, the art that tended to be the psychologization ofa human subject, so that the Western art began to lose its traditional characters (Baqir, 2013).

Of course this influence also ultimately came to Indonesia, which caused anxiety for Claire Holt, an American researcher, who in 1930 specifically came to Indonesia to study dance. He believed that the islands located in the Equator, especially Java, were a place of living tradition of the dance (Holt 1967: 2). In a weekly magazine in 1930, he wrote an article with colored photos of the palace dancers with the title: "The West Begins to Quicken Ancient Java's Slow Moving Life".

"The country is ruled by the Western World. Production and exploitation of land and industry tend toward American efficiency. Amid the advancing tide of modern civilization, however, still gleam in medieval color and splendor the courts of the Javanese princes. Are they anachronism presently doomed to extincton? Or will these symbols of ancient Java continues their strange existence side by side with modern factories, Western legislation, among railways and automobiles and occidental ideas brought by th government to school and shop. What is their meaning in a land charged by two powers - the slow broad current of old Hindu-javanese traditions and the quick vibrating rhythm of the efficient West? Two ernomous power which cannot merge. Between them stands the enlightened twentieth century Javanese and contemplates the spectacle"(1930: 7).

It is reasonable for Holt if he was so worried about the sustainability of the art tradition in Java, especially Javanese classical dance which its slowness was so ri- veting, describing the great inner dimensions of the dance. The dance form itself is a vehicle for self-knowing and spiritual growth, he said in Deena Burton's book "Sitting at The Feet of Gurus: The Life and Dance Ethnography of Claire Holt" (Burton, 2009: 56). He completely understood that basically traditional arts, such as Javanese classical dance style of Yogyakarta is the art of conveying messages of the truth transmitted to the masters or the person who qualified in their field. The messages are hidden in the symbols, which have full of meanings that might be revealed to improve the inner of artists or appreciators of art itself.

Before going any further, we should understand what the meaning of the word 'traditional'. The word of ' tradition ' comes from English like the words of action, connection, resolution, or justification. But actually the roots of tradition itself comes from the Latin traditio; and tradition is a noun form of the verb trader or traderer, meaning "to deliver, to submit to secure, orto transmit" or in other words, the tradition is "something that is transmitted" (Muqi, 2013: 11).

Seyyed Hossein Nasr suggests the tradition is not only limited to customs that handed down generation to generation. Moreover, it is also something that comes from the sky and has a very wide scope. It is not only applied in the realm of metaphysics and religion, but also expressed in various applied fields, such as traditional arts, traditional sciences, and also traditional social structures since it is based on divine principles applied in all aspects of human life (Nasr, 2010: 180-181).

In other words, culture, customs, art, etc. are ramifications of the tradition itself. The Indonesian word 'budaya' (culture in English) comes from the word buddhi (intellect) and daya (power), derived from the Sanskrit words, meaning 'power', that is the key to rediscover transcendental realities or 
pure consciousness. Whereas, the word adat comes from Arabic al-'adah which means 'to restore something according to its original state or to the true reality' (Baqir, 2016).

From the above explanation, it is clear that arts when viewed from its relation with tradition, culture or custom, can not be separated from divine principles or true reality, and not only limited to custom which passed down from generation to generation.

Seyyed Hossein Nasr confirms that the arts, through traditional ways, should convey the truth, the beauty and universal meanings and untied to the individual ego of artists (Nasr, 2010: 239). As the requirement to achieve the flow according to Csikszentmihalyi, or taksu, the artist must break away from his individual ego (1990: 4).

From traditional dance area, Ben Suharto said in his book, The Concept of Matayain Yogyakarta Dance, that the performance of Classical Javanese dance actually eliminates the self-ego of the dancers by expecting the audience concentrated only on watching the dance instead of watching the dancers (1998: 17-18). It means that a dancer in traditional arts only one element, as well as gamelan, pendapa, a place of dance and various other elements that blend in a series as a symbol of jagad alit and jagad ageng in the universe. "Indeed, at the old age people created art because of their heart feeling, not for entertaining, but as a means of communication to the God. That is what missing today. Currently the dance is only for klangenan, just for entertaining, Sal Murgiyanto said, a maestro of performing art in his home in Yogyakarta (interview, 2014).

In traditional society, people started their activity by performing the ritual before. Because of the intention of ing sun allwe have done is merely an embodiment of humility and offerings of a kawula towards his Gusti, the servant against his Lord,such as fasting before dancing bedhaya dance.
Lelaku or ceremonial rituals which generally guided by rules or existing sources, are basically aimed to raise consciousness and sense of feeling, so that the artist can be more intense to communicate with The Creator. No wonder if what is produced later is something beyond hers/him (supra individual).

\section{CONCLUSION}

From above description, it can be known the differences between traditional and modern societies regarding the arts. In traditional society, as represented by the artists, returns everything to its origin that is God, the spiritual world. They do nothing for the sake of their ego. In other words, they do everything as their offerings to God, not for showing their capability or self-proofing.

This why, according to Seyyed Hossein Nasr, people are always eager to back to Bali island. Because in Bali, they still feel the living traditions from hand made art objects, as well as performing arts and music. People hope to "escape" for a while from the modern worldthat had been filled with ego. Although modernization has greatly damaged or urged art products to museums, or performing arts can no longer be found in the midst of living society, at least traditions can still be found, even only in concert halls (Nasr, 2010: 258).

Following the tradition does not mean stagnate, or do not follow the changes. Following the tradition does not mean retrogress or back to the past to simply enjoy the nostalgia of the triumph that ever existed. But by understanding the messages behind symbolsof artistic traditions, we are brought to remember the presence of the Almighty. Any changes are required for the existence as a guide, or in this caseprinciplethat can continue to be upheld.

Holding tradition is a solid guidance that returns a person to his own authentic- 
ity, to his Lord. While the truth offered by modernization is relative. The fading tradition makes a society lost its grip. As Jayabaya's prediction, 'in Java; wong Jowo dadi ilang jawane, the Javanese are increasingly deprived of their 'feeling' due to the increasingly loosened relationship they have with the Creator, with his true self. Of course we cannot force everyone to hold on to tradition, because it is a free choice for every individual with its own consequences.

The artists, who are aware of the importance of a solid milestone in carrying out its artistic mission, know that the milestone keeps the unbound divine wisdom to be explored. The art, such as dance, is not just a linear of physical journey but also mental and spiritual one. The symbolization expressed through the gestures that flow in dance is a picture of a multi-dimensional journey, as well as a means of climbing around its own life cycle towards the Self.

That is the reasonwhy not all traditional artists can produce soulful works. It is required a long staircase process and it is not easy to reach and arrive at that stage; itneeds a process of self-contemplation that keep him humble. Perhaps, in this case we can re-contemplate the meaning of the Javanese proverb: ojo rumongso biso, nanging biso rumongso [no feeling of capability, but having sense of feeling].

Not all works of the traditional artists appear perfectly. Therefore, the deepen factors is not easy, the imperfections of works can also be caused by many other factors. Among others are the lack of experience (inexperience) or the incompetence of the artist. It could also be due to a problem in terms of intelligence or spirituality, or of the absence of 'apprenticeship' or nyantrik periods and many other factors.

But of course there is nothing wrong or right here. It does not matter if someone needs to channel his talent by creating a work on the sake of entertaining, In traditional societies, art is like the so-called 'sensible' consolation or solace sensorial, in the sense that art as entertainment and sensorial pleasure to satisfy the needs at that particular time. If this gives good impact for people who enjoy his work, and for the creator of the art himself, why not?

\section{Bibliography}

Ali Muqi

2013 "Sekilas tentang Tradisi". Majalah Pondok Tradisi. Edisi 2 Bulan Juni 2013.

Benedictus Suharto

1998 Dance Power: The Concept of Mataya in Yogyakarta Dance. Bandung: Masyarakat Seni Pertunjukan Indonesia.

Bulantrisna Djelantik

2012 "Pengantar Acara Maestro Maestro\#6". Program Pertunjukan, 11 November 2012.

Burton, Deena

2009 Sitting at The Feet of Gurus: The Life and Dance Ethnography of Claire Holt. Bloomington: Xlibris Corp.

Csikszentmihalyi, Mihaly

1990 "Flow: The Psychology of Optimal Experience". New York: Harper and Row.

E. Kristi Poerwandari

2005 Pendekatan Kualitatif dalam Penelitian Psikologi. Jakarta: LP3ES.

Guènon, Renè

1996 The Crisis of The Modern World. Hillsdale: Sophia Perennis.

Holt, Claire

1930 "The west begins to quicken ancient Java's Slow Moving Life" dalam The Sunday World Magazine. 28 Desember 1930. 


\section{$-$}

1967 “The Dance in Java”.XI, 1-8. Makalah Perpustakaan Mangkunegaran.

Maryaeni

2012 Metode Penelitian Kebudayaan. Jakarta: PT Bumi Aksara.

Muhamad Baqir

2013 “Kajian ‘Berjalan di Taman Spiritual"' Kajian Paramadina.

$--$

2016 “Kajian 'Berjalan di Taman Spiritual"'. Kajian Paramadina.
Nasr, Seyyed Hossein and Ramin Jahan begloo 2010 In Search of The Sacred. Santa Barbara: Praeger, an Imprint of ABCCLIQ, LLC.

Webtografi:

http://www.newworldencyclopedia.org/ entry/Industrial_Revolution, accessed at 10 June 2015.

Oxford English Dictionary Online, www. oxforddictionaries.com. accessed at 16 December 2015

http://www.ted.com/talks/elizabeth_gilbert_on_genius?language $=\mathrm{en}$, accessed at 30 November 2013 